 \\ International Journal of Social Sciences and Management \\ A Rapid Publishing Journal
}

ISSN 2091-2986

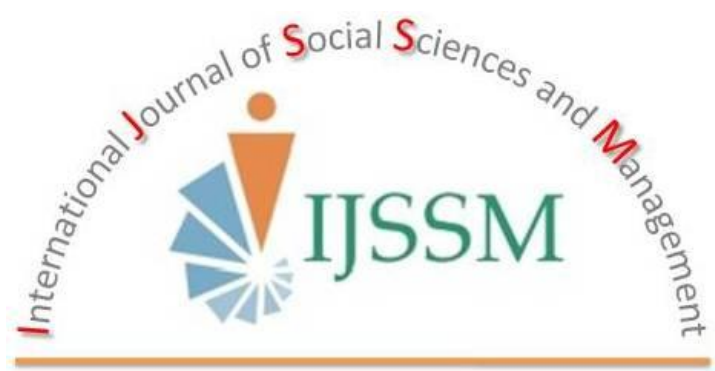

\section{Indexing and Abstracting}

CrossRef, Google Scholar, International Society of Universal Research in Sciences (EyeSource), Journal TOCs, New Jour, Scientific Indexing Services, InfoBase Index, Open Academic Journals Index (OAJI), Scholarsteer, Jour Informatics, Directory of Research Journals Indexing (DRJI), International Society for Research Activity (ISRA): Journal Impact Factor (JIF), Simon Fraser University Library, etc.

Vol-2(2) April, 2015 


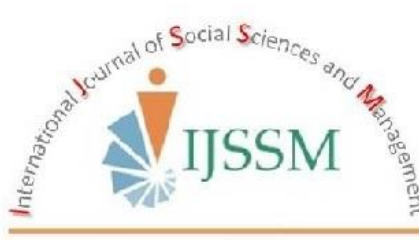

\title{
STUDY OF AROMATIC AND MEDICATED PLANTS IN UTTRAKHAND, INDIA: WITH FOCUS ON ROLE IN EMPLOYMENT GENERATION AND SUPPLY CHAIN MANAGEMENT
}

\author{
Ruchita Pangriya* \\ Freelancer - Management Consultant (Masters in Business Administration, UGC-NET) C V Raman Nagar, Bangalore \\ Email: rpangriya6@gmail.com
}

\begin{abstract}
India is one of the major exporters of crude drugs including Medicated and Aromatic Plants globally. As per the latest and most recent data available, in 2012-2013 India's total export of Ayush, Medicinal herbs and their value added products was USD 395.58 million. State of Uttarakhand in India is a natural habitat of the prosperous varieties of herbs, medicinal and aromatic plant species. The Government of Uttarakhand state has also realised this big potential and is continuously trying to tap this wealth. In 2012-2013 the state exported culinary herbs, Aromatic products and medicated products worth`29.0 crore. The aim of this study of MAP products in Uttarakhand state is to evaluate the impact of cultivation of MAP products, in relation to the new employment generation and also to study the supply chain management in context to the activities of various agencies engaged in collection, distribution and auction. This paper focuses on the cultivation program running in Uttrakhand by HRDI and its importance in employment generation in the hilly districts. It is very evident in today's time that a strong supply chain is basic necessity for every organised business to sustain and to be successful in long run. This paper also studies the existing supply chain for MAP products and investigates the loopholes for further improvement so that the cultivators of MAP get maximum monetary benefits with minimum problems. In addition to that, role of different corporations like KMVN, GMVN and Bhesaj Corporation in marketing of these MAP products has also been discussed under the presented study.
\end{abstract}

Key words: MAP; Herbs; Supply Chain Management; Rural Marketing; Bhesaj Sangh; Employment; cultivation.

Abbreviations: MAP: Medicated and Aromatic Plants; HRDI: Herbal Research \& Development Institute; KMVN: Kumaon Mandal Vikas Nigam; GMVN: Garhwal Mandal Vikas Nigam

\section{Introduction}

Indian herbs are known all over the world for the medicinal properties. The Indian states which are major producer of herbal plants having the highest medicinal value are Gujarat, Rajasthan, Haryana, Tamil Nadu, Andhra and the states located in Himalayan range. India, followed by China is the largest producer of medicinal plants, having more than $40 \%$ of the global diversity (Financial express 2008).

About $90 \%$ of the herbs and medicinal plants in India are collected from the forest. The collection and marketing of these plants provides an important source of income for communities living in local areas. Medicinal and aromatic plants (MAPs) are traded both as raw materials and as processed finished products. Demand for wider variety of species is increasing day by day as more and more people are turning towards Ayurvedic treatment for complex ailments. The WHO estimates that by 2050 the trade of medicinal plants will be up to USD \$ 5 Trillion globally.

\section{Herbs export from India}

India is one of the major exporters of crude drugs primarily to the six developed countries: USA, Germany, France, Switzerland, UK and Japan who share between them 75 to $80 \%$ of the total export of crude drugs from India (Simon Mills and Joey Lee 2011). The major herbal exports of India include Psyllium seeds, Senna leaves and pads, and various other herbs and herbal products. Among all Psyllium husk (isobgul husk) contribute a major chunk of herbal exports. As per the statistics available from Pharmexcil, China is the top country leading in the world in the export of herbals followed by India (Pharmabiz.com, 2012). Some of the measures taken by the Government for encouraging exports from India are: (Ministry of Commerce \& Industry, 2009)

- Awarding of AYUSH Marks for Quality Certification and recognition for AYUSH products in international markets.

- Voluntary certification of quality of Ayurveda, Siddha, Unani (ASU) products through Quality Council of India. 
- $\quad$ Supporting the industry members to participate in various events related to promotion of AYUSH products, medicinal herbs and their value added product exports, including traditional medicine exhibitions such as Vita foods at Geneva and Supply Side West at USA.

- Supporting the industry to organize Reverse Buyer Seller Meet focused to herbals and AYUSH products.

- To enlarge and diversify export production and exports of identified medicinal plants and herbs through the Export Promotion Council, SHEFEXIL.

India's export of Ayush, Medicinal herbs and their value added products (USD million) for year 2010 to 2013 is shown in following tables. (Table-1 and Table-2)

From this information we can say that the market of herb and herbal products is increasing steadily, India exports for the year 2012-13 was about USD 395.58 million, vis-à-vis
USD million 358.30 with a growth rate of $10.40 \%$ over the previous year.

Table 1: Summary of India's Export of Ayush, Medicinal herbs and their value added products (USD million)

\begin{tabular}{lccc}
\hline Commodity & $\mathbf{2 0 1 0 -}$ & $\mathbf{2 0 1 1 -}$ & $\mathbf{2 0 1 2 -}$ \\
& $\mathbf{1 1}$ & $\mathbf{1 2}$ & $\mathbf{1 3}$ \\
\hline Ayush & 156.96 & 182.18 & 163.44 \\
Medicinal herbs and their value & 141.63 & 176.12 & 232.14 \\
added products & 298.59 & 358.30 & 395.58 \\
Total &
\end{tabular}

[Source: Ministry of Commerce \& Industry 09-December, 2013 16:19 IST]

According to the study of Associated Chambers of Commerce and Industry (ASSOCHAM) Indian herbal industry to double by 2015.According to this study the domestic herbal industry will grow rapidly in coming years and by 2015, size of the domestic market will rise to 15,000 crore, reflecting a compound growth of over 20 percent. According to this study the global demand for the Indian herbs by 2015 is shown in table-3 (SME Times News, 2010).

Table 2: Breakup of India's exports of Ayush, Medicinal herbs and their value added products (USD million)

\begin{tabular}{|c|c|c|c|c|c|}
\hline Sr. No & Country & Category & 2010-2011 & 2011-2012 & 2012-2013 \\
\hline \multirow[t]{2}{*}{1} & USA & Herbals & 52.69 & 70.38 & 107.75 \\
\hline & & Ayush & 23.29 & 12.78 & 28.35 \\
\hline \multirow[t]{2}{*}{2} & Japan & Herbals & 7.19 & 8.43 & 12.96 \\
\hline & & Ayush & 5.66 & 18.81 & 16.68 \\
\hline \multirow[t]{2}{*}{3} & Pakistan & Herbals & 13.99 & 18.02 & 19.93 \\
\hline & & Ayush & 1.06 & 1.83 & 1.77 \\
\hline \multirow[t]{2}{*}{4} & UAE & Herbals & 1.16 & 1.72 & 1.36 \\
\hline & & Ayush & 11.1 & 17.35 & 15.56 \\
\hline \multirow[t]{2}{*}{5} & Germany & Herbals & 9.22 & 11.1 & 15.29 \\
\hline & & Ayush & 0.85 & 1.62 & 1.06 \\
\hline \multirow[t]{2}{*}{6} & Russia & Herbals & 0.11 & 0.11 & 0.12 \\
\hline & & Ayush & 30.14 & 38.52 & 14.64 \\
\hline \multirow[t]{2}{*}{7} & Nepal & Herbals & 0.83 & 0.92 & 0.6 \\
\hline & & Ayush & 7.97 & 9.43 & 9.91 \\
\hline \multirow[t]{2}{*}{8} & Australia & Herbals & 2.42 & 3.42 & 3.66 \\
\hline & & Ayush & 2.89 & 4.37 & 6.64 \\
\hline \multirow[t]{2}{*}{9} & Bangladesh & Herbals & 5.34 & 5.42 & 6.96 \\
\hline & & Ayush & 0.17 & 0.51 & 0.37 \\
\hline \multirow[t]{4}{*}{10} & Vietnam & Herbals & 4.38 & 3.74 & 6.61 \\
\hline & & Ayush & 0.79 & 0.87 & 0.5 \\
\hline & World total & Herbals & 141.67 & 176.25 & 232.14 \\
\hline & & Ayush & 156.99 & 182.23 & 163.44 \\
\hline
\end{tabular}

[Source: Ministry of Commerce \& Industry09-December, 2013 16:19 IST]

Table 3: Global demand for Indian herbs by 2015.

\begin{tabular}{ll}
\hline Markets & Projected Demand (For 2015) \\
\hline Europe & US\$ 70 Billion \\
North America & US\$ 25 Billion \\
China & US\$ 12 Billion \\
India & US\$ 3 Billion \\
Others & US\$ 30 Billion \\
Total & US\$ 140 Billion \\
\hline
\end{tabular}

[Source: SME Times News Bureau, 06 Mar, 2010] 


\section{Uttrakhand herbs and aromatic plants production}

Uttrakhand, located at the foothills of the Himalayas, is characterized by diverse geographical features ranging from snow-capped mountain peaks in the North to tropical forests in the South. It has been divided into two regions- the western region- Garhwal Mandal and the eastern regionKumaon Mandal. The State is having about $61.1 \%$ area under forests. In 2012-2013 the state exported culinary herbs \& aromatic produce worth 29.0 crore (shm.uk.gov.in). Uttrakhand is a storehouse of a rich variety herbs and medicinal and aromatic plant species. The Government intends to exploit this advantage. Uttrakhand has observed an increase in the area under cultivation of aromatic and medicinal plants. The number of farmers engaged in cultivation of aromatic plants in Uttrakhand has dramatically increased from 301 in 2003-04 to 2714 in 2006-2007 and the area under aromatic plants has increased tenfold. (forest.uk.gov.in)

Uttrakhand has been declared a herbal state, and for taking care of the multifarious aspects of the MAP sector, Herbal Research \& Development Institute at Gopeshwar (1989) has been named as the apex agency in 1989 for conservation, development and sustainable utilization of the valuable Medicinal and Aromatic Plant resources of Uttrakhand. The major developments are :( Tribuneindia.com, 2010)

- Three nurseries in each block.

- Herbal gardens in every district.

- 70 collection centers connected to mandis at Rishikesh, Tanakpur and Ramnagar.

- Provision of manpower for research and development.

- Farmers to get training in herbal cultivation and post-harvesting techniques.

- Certification for content at laboratories in Gopeshwar and Selaqui.

- Creation of the State Plant Board office in the capital.

Table 4: The distribution of medicinal plants by their habit in Uttrakhand

\begin{tabular}{ll}
\hline Species & Percentage \\
\hline Herbs & $32 \%$ \\
Shrubs & $20 \%$ \\
Trees & $33 \%$ \\
Climbers & $12 \%$ \\
Others & $3 \%$ \\
\hline
\end{tabular}

[Source: NRIF - Final Report on Pilot study on mechanism for sustainable development and promotion for herbal \& medicinal plants in the state Uttaranchal.]

The State is blessed with thousands of species. About 320 species have been identified having medicinal value. The forest department has reported about 175 species being commercially exploited and traded. The number of species reported for Kumaon is 304 while 288 is reported for Garhwal region. It is estimated that the State is well positioned to generate revenue of about 1, 000 crore annually through medicinal herbs trade. (NRIF, 2004). The distribution of medicinal plants by their habit in Uttrakhand is shown in Table-4.

\section{Literature Review}

The MAP sector is estimated to generate about 40 million days of employment nationwide per annum. In addition to the contribution to national GDP, a major proportion of this labor contributes towards the livelihoods of some of the poorest and most backward in terms of finance in Indian society. Worldwide the people, who have very limited alternate livelihood measures and have only primarily survival economies, wild collection from forests and green areas is the main source of income for survival. Similarly the Himalayan herbs give cash income to the households of primal and local communities, the landless and poor cultivators in the Himalayas.

A study done by Simon Mills \& Joey Lee summarized that in the Central Himalayas region indicated that about 2,000 person-days/year of direct employment is generated through MAP related work in an average village of 150 households, of which 50 households are involved in such work; in addition indirect livelihoods (50,000 men-days) are generated through MAP collection for consumption purposes.( Simon Mills and Joey Lee,2011). In India, there are about another 20 well-recognized manufactures of herbal drugs and 140 medium or small-scale manufactures. In addition, thousands of vaidyas (traditional healers) have their own miniature manufacturing facilities (Polshettiwar, 2006). MAPs are selected as a notable livehood -focused venture along with traditional farming system, which can provide farmers a regular Income (Uniyal, R.C., Unyal, M.R. \& Jain P, 2000).

As the final destination of every product is its consumers, so a strong supply chain is necessity for every business. In a broad sense supply chain or a value chain describes the sequence of activities required to make a finished product from its initial starting material (e.g. from field crop or gathered wild material) (Chopra and Meindl 2004) (Fig. 2). Although there are plenty of reports on various products like tea and coffee, but only a limited studies on supply chain of MAP products. As rightly said by Somasekhar, Raju et.al., that the agri-supply chain system of the country is determined by different sartorial issues like dominance of small/ marginal farmers because It has been empirically recognized that small farms produce more per hectare than their larger counterparts, fragmented supply chains, absence of scale economies, low level of processing/value addition, inadequacy of marketing infrastructure etc (Somashekhar I C, Dr.J.K.Raju, Dr.Hema Patil,2007; infochangeindia.org, 2010)

The assessment of the relative benefits to the primary producers of horticultural products like herbs and rare plants, as compared to middlemen, wholesalers and retailers 
is very necessary. Often it was found that farmers or gatherers only obtained a minimal share in the benefits of such products (Litvinoff and Madeley 2007) Growers of medicinal plants have little direct access to the market, resulting in high degree of wastage, and low returns for farmers. The marketing channel for medicinal plant parts in particular, is unorganized and unregulated. This allows a great amount of illegal trade, unfair practices and share of revenues, and inadequate attention paid to quality control. Lack of information on the source of raw materials, the actual traded volumes, toxicity and heavy metals related information, are some other key concerns of this burgeoning sector (Simon Mills and Joey Lee, 2011).

Uttrakhand has suitable climate condition for cultivation of MAP's and recently some industries has been established for promoting MAP's products and in this way farmers find it a lucrative option for live hood enhancement as against the traditional farming (Nautiyal, M.C., Nautiyal, B.P.2004). Because of a variety of agro-climatic niches, the state has tremendous potential to emerge as a regular supplier of medicinal and aromatic plants to other states in the country and even outside of the country (Samant SS, Dhar U \& Palni LMS,1998). Given the terrain of the state and favorable climatic conditions, medicinal and aromatic plants continues to be the major source of income for more than three-fourths of the state's population. Many medicinal plants can be cultivated on poor quality land under low rainfall and moisture conditions where other crops do not grow (Rajasekharan PE, Ganeshan S, 2002).

\section{Objective}

The primary objectives of the study, presented thru this paper are as follow:

- To study the importance of cultivation of MAP products in context to the new employment generation in Uttrakhand state of India.

- To study the supply chain dynamics of herbs and aromatic products (MAP) and finding the loophole and suggesting improvements.

\section{Methodology}

The research done during study is exploratory in nature. The research is focused on Uttrakhand state of India and its markets covering various district viz. Pithoragarh, Champawat, Bageshwer, Chamoli, Almora, Rudraprayag,Tehri, Uttrakashi . The analysis is based on primary as well as secondary data. The primary data is collected by a focus group interview of traders and farmers. The interview covers several open ended questions. For collecting different information, discussions were done with scientists of HRDI, Gopeshwer (Uttarakhand) and officials of district herb centres in different districts. The secondary data is collected from various published journals, reports, newspaper articles and HRDI website. For analysis purpose, the data percentage, average and grouping methods are used.

\section{Findings}

Employment generation through MAP cultivation: The number of farmers engaged in cultivation of aromatic plants in Uttarakhand has dramatically increased from 301 in 2003-04 to 2714 in 2006-2007 due to various new promotional schemes launched by government and the area under aromatic plants has increased tenfold. Herbal Research and Development Institute is prime agency of state government responsible for the cultivation of medicinal and aromatic plants (MAPs) and overall development of MAPs sector in the state. The following table gives detailed distribution district wise of the new farmers who got employment thru MAP cultivation program, in Uttrakhand's various districts in last 05 years starting from 2008-09. The data available and presented below in tabular form is for last 05 revenue years (2008-09, 2009-10, 2010-11, 2011-12 \& 2012-13) and the numbers are only of new cultivators, for particular years only.

Table 5: Number of new farmers registered under MAP cultivation program in Uttrakhand in last 5 years.

\begin{tabular}{lccccc}
\hline District & $\mathbf{2 0 0 8 - 0 9}$ & $\mathbf{2 0 0 9 - 1 0}$ & $\mathbf{2 0 1 0 - 1 1}$ & $\mathbf{2 0 1 1 - 1 2}$ & $\mathbf{2 0 1 2 - 1 3}$ \\
\hline Almora & 585 & 113 & 396 & 186 & 262 \\
Pithoragarh & 293 & 245 & 273 & 208 & 101 \\
Champawat & 273 & 354 & 67 & 115 & 112 \\
Chamoli & 113 & 396 & 123 & 171 & 113 \\
Tehri & 371 & 208 & 316 & 159 & 325 \\
Uttarkashi & 192 & 132 & 480 & 96 & 396 \\
Rudarprayag & 399 & 205 & 304 & 58 & 62 \\
Bageshwar & 304 & 85 & 160 & 67 & 118 \\
Total & 2530 & 1738 & 2119 & 1060 & 1489 \\
\hline
\end{tabular}

[Source: Data Analysis]

So as per the tabular data presented above, the MAP cultivation program got successful in generating employment for approximately 8936 peoples in Uttrakhand from the year 2008-2013, as per the data available. Considering the total new employment generation in the state, this constitutes a good percentage.

The details available reflect that this new employment generation has helped in increasing total revenue generation from the state. One interesting fact reflects from the above table is that number of new farmers getting engaged in MAP cultivation is not continuously increasing. The probable reason for this is that the cultivation land in state is limited due to tough geographical terrains and already many people have adopted this cultivation in past years. Year wise estimated production in different districts by new registered farmers (Individual Year) is given in following table-6. The details for estimated earnings by cultivators from MAP products are tabulated and summarized in below table-7. 
Table 6: Estimated Production in $\mathrm{Kg}$, in different Year by new registered farmers.

\begin{tabular}{lccccc}
\hline District & $\mathbf{2 0 0 8 - 2 0 0 9}$ & $\mathbf{2 0 0 9 - 2 0 1 0}$ & $\mathbf{2 0 1 0 - 2 0 1 1}$ & $\mathbf{2 0 1 1 - 2 0 1 2}$ & $\mathbf{2 0 1 2 - 2 0 1 3}$ \\
\hline Almora & 196908 & 28295 & 220204 & 247190 & 68191 \\
Pithoragarh & 62419 & 77809 & 321482.3 & 162543 & 91908 \\
Champawat & 49527 & 277483 & 222830 & 547985 & 203959 \\
Chamoli & 22039 & 91306.32 & 32140 & 104006 & 20269.25 \\
Tehri & 175741 & 18720 & 68387 & 81581.5 & 85778.45 \\
Uttarkashi & 50481 & 74903 & 124238.9 & 16831.8 & 109854.065 \\
Rudarprayag & 85573 & 25762 & 168725 & 9410 & 7782 \\
Bageshwer & 379732 & 76768 & 73275 & 141311 & 30278 \\
\hline
\end{tabular}

[Source: Data Analysis]

Table 7: Estimated earnings (In Lakhs) by the cultivation of top thirteen MAP products.

\begin{tabular}{lcccccccc}
\hline MAP & Almora & Pithoragarh & Champawat & Chamoli & Tehri & Uttarkashi & Rudarprayag & Bageshwar \\
\hline Kuth & 0.00 & 39.72 & 0.00 & 188.77 & 158.02 & 475.74 & 99.63 & 41.03 \\
Badi Elaichi & 11.97 & 31.95 & 8.28 & 706.54 & 44.27 & 39.16 & 83.17 & 0.65 \\
Tejpat & 25.91 & 291.21 & 304.06 & 30.88 & 46.03 & 36.10 & 24.07 & 130.30 \\
Kutki & 0.00 & 3.12 & 0.00 & 274.73 & 40.94 & 73.79 & 192.98 & 237.68 \\
Satawar & 12.28 & 1.13 & 247.09 & 6.83 & 25.14 & 16.69 & 3.51 & 6.94 \\
Peele Shatavari & 0.00 & 0.00 & 253.90 & 0.00 & 0.00 & 0.00 & 0.00 & 0.00 \\
Kilmoda & 136.14 & 0.00 & 23.81 & 0.20 & 0.00 & 2.04 & 0.00 & 66.19 \\
Kapur kachri & 6.88 & 5.64 & 0.00 & 0.00 & 0.00 & 0.14 & 3.85 & 143.80 \\
Reetha & 9.98 & 34.98 & 13.14 & 12.27 & 14.68 & 24.34 & 41.30 & 9.51 \\
Bach & 62.33 & 8.98 & 32.83 & 14.94 & 0.00 & 6.48 & 0.00 & 12.67 \\
Lemon Grass & 3.80 & 0.36 & 2.56 & 0.97 & 58.11 & 0.00 & 10.01 & 3.16 \\
Mitha & 0.00 & 0.00 & 0.00 & 0.00 & 0.00 & 74.48 & 0.00 & 0.00 \\
Sarpagandha & 0.00 & 16.25 & 0.00 & 2.00 & 17.09 & 0.00 & 0.00 & 0.00 \\
Total & 269.28 & 433.33 & 885.67 & 1238.12 & 404.27 & 748.95 & 458.52 & 651.92 \\
(In Lakhs) & & & & & & & &
\end{tabular}

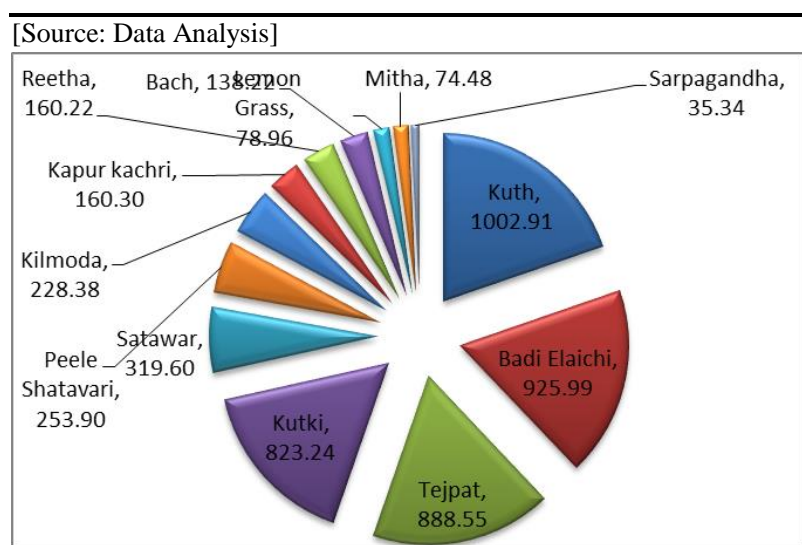

Fig. 1: Total generated money (In lakhs) from 2008-09 for next 05 years from 12 major MAP products in Uttarakhand, by new cultivators.

The farmers registered under cultivation scheme in 20082009 were 2530 , in 2009-2010 were 1738, in 2010-2011 were 2119, in 2011-2012 were 1060 and in 2012-2013 were 1489.Total registration in these five years was 8936 farmers, which was about $228.77 \%$ higher than 2006-2007. Total number of new registered farmers under HRDI for cultivation of Medicinal and Aromatic Plants of all five years from 2008-2013 in district Almora is 1542, Pithoragarh is 1120, Champawat is 921, Chamoli is 916, Tehri is 1379 , Uttarkashi is 1296 , Rudraprayag is 1028 ,
Bageshwer is 734.The cultivation program covers 69 different varieties, viz. Tejpat, Reetha, Kirmoda, Satavar, Bach, Badi Elaichi, Samewa, Kuth, Kutki, Lemon Grass, Kala Jeera, Aloe Vera (Grihat Kumari), Rosemary, Amla, Baheda, Artemisia, Giloy, Ateesh, Chamomile, Mandukaparni, Panger, Akhrot (Juglandaceae), Gudbach, Faran, Indrayan, Argentum, Tagar, Patherchoor, Coleus, Mitha, Kapur kachri , Timur, Haran, Daruhaldi, Thuneru, Roota Grevelance, Compare, Compare Compare, Digitalis Purpurea, Geranium, Palmarosa,, Sarpagandha, Van Ajwain, Orgayans, Gwar Patha, Chipi , Chura , Jambu, Gandrayan, Brahmi, Kalihar, Coleus Forskohlii, Caram Carvi, Marjoram, Parsley, Stevia, Rose, Genda, Lavender, Ashwagandha, Chirata, Agemesh, Peele Shatavari, Kaal Megh, Pashanbhed, Akarkara, Vidari-kand, Bichhu Ghass.

\section{Supply Chain of MAP Products}

Various intermediaries in supply chain of MAP products are cultivators, collectors from forest, village level collation centers, local collectors Bheshaj Sangh's (Cooperative societies); Kumaon Mandal Vikas Nigam and, Gharwal Vikas Mandal Nigam, Wholesalers (mandies), stockiest, companies and retail consumers. 


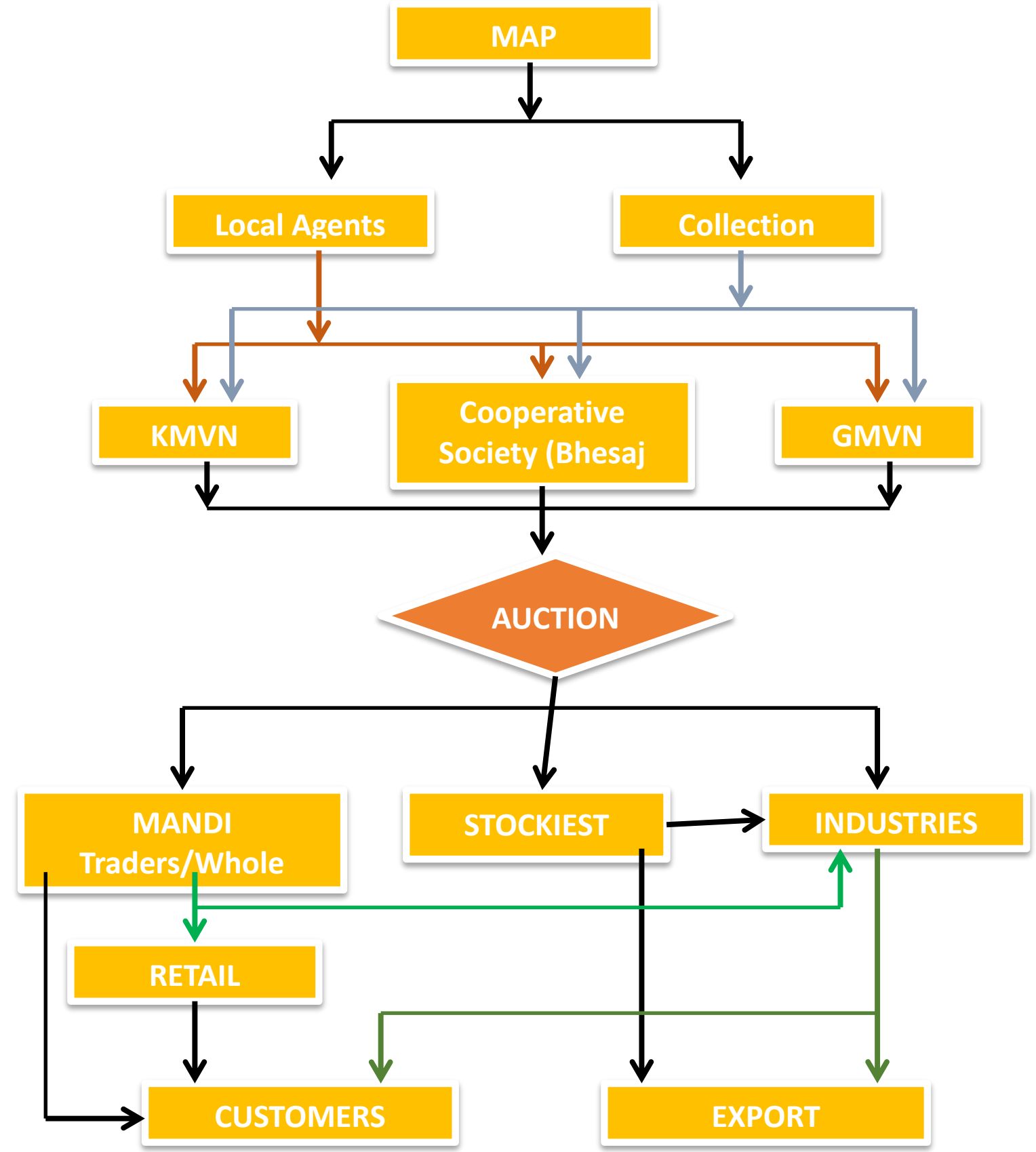

Fig. 2: Supply Chain of medicated and aromatic plants in Uttrakhand (Regular Trade Channels) [Source: Market Information]

The Kumoun Mandal Vikas Nigam, Bheshaj Sangh's (Cooperative societies) and Garhwal Mandal Vikas Nigam are the nodal agencies for marketing of MAP products in Uttrakhand. The main roles of these organizations fixed by government are:

1. Direct Purchase: Under this role these organizations can purchase MAP products direct from the cultivators and pay them for their crops. All the other responsibility like warehousing, processing, transportation, record maintenance, auction etc is done by these organizations.

2. Bandhak (Mortgage): Under this role these organization can give advance payment, nearly about $70 \%$ to cultivators for their commodity value for their urgent need before auction, and rest of amount $30 \%$ after the auction.

3. Commission agent: Under this role of commission agent these organizations works as a commission agents and arrange auction in Mandies. They are nothing to do with other activities like warehousing, processing, transportation. The Kumoun Mandal Vikas Nigam is taking royalty of $12.5 \%$ and the district Bhesag Corporations are taking the royalty of $10 \%$ of the commodity auction prices.

Apart from the above supply chain system there are some other chains also by which the crop reaches to the industries. Because of the presence of multiple stakeholders the price received by the farmers is very low in comparison to the price paid by the industry. These chains are very popular 
because by these methods the cultivators and the collectors can earn more money.

1. Collector/Cultivator $\rightarrow$ Pharmacy/Industry

In this case the industry people directly make contact with with farmers and pay full price to them. Farmers or the collectors of MAP products get $100 \%$ price paid by the pharmacy or by industry.

2. Collector/Cultivator $\rightarrow$ Traders $\rightarrow$ Pharmacy/Industry

In this case the traders are in between farmers and the companies. This channel is very common at places with difficult geographic conditions where the transportation is a big problem. In these cases farmers get only $20 \%$ of the price paid by the pharmacy or industry.

\section{Conclusion \& Recommendation}

Cultivation Program: The MAP cultivation programs providing the great opportunity to farmers and unemployed youth to get employment at their own places. These crops can be produced in very high altitude and those parts also where it is difficult to grow traditional crops. The environment of Uttrakhand is very supportive to the growth of these MAP. So many illiterate women and villagers are now earning good amount of money by growing MAP products under cultivation programs.

There are various schemes started by Uttarakhand government like Jari Buti Yojana, National mission on Medicinal Plants, Aawala Mission in Uttarakhand, tribal sub-plan projects etc focuses on increase the cultivation of Medicinal and Aromatic Plants in districts, registration of MAP cultivators/farmers, quality planting material production in departmental nurseries, subsidy distribution to MAP growers, establishment of distillation unit for aromatic crop ,training to MAP cultivators/ farmers etc are in main focus.

Although the cultivation program is going in the right direction but there are so many areas under which there is a huge scope of improvement. These areas are quality, packaging, marketing and promotion. In Uttrakhand the marketing and promotion part of MAP needs a lot of improvement.

Supply Chain Management: Government of Uttrakhand state has established a formal supply chain of MAP products which include procurement and distribution of products through various government agencies which act as intermediaries like BHESAJ Corporation, KMVN and GMVN. But due to some short comings in the chain, very less quantity of total cultivated products is going through this chain.

The prime reason for this is, the price paid by industry for MAP products directly to MAP cultivators or unofficial inter-mediatory or agents is very high, in comparison to the price that cultivators get after selling through government nodal agencies.

Farmers are also supportive of the system of direct selling to agents and industries as they earn quick and thick amount of money by this. But due to this government exchequers face big loss of money, which could have been earned in the form of royalties from these crops.

Another indirect loss of this is, the official data available to government of production quantity, cultivation pattern of different crops is not realistic and appropriate. Due to this, various government schemes implemented for improvement of MAP product cultivators are not very effective.

So in order to improve the overall system and supply chain of MAP products, following suggestions are presented as a conclusion of this study:

- During study it was observed, that although the Bhesag Corporation, KMVM and GMVN have three different roles as direct collector, Bandhak and commission agent, but in most of the district these organizations are focusing only on the third role i.e. Commission agent role.

- Under this role the activities of these organisations get limited and they focus primarily on the auction activity. This is relatively an easier role, as major action in this is arranging auctions at different designated places and collecting the royalty from auctioned items, based on their selling prices. In this case, the farmer is responsible for processing of the product, arranging warehouse, transportation and taking related risks. Whereas Bhesaj, KMVN or GMVN concentrate on Auction part.

- In order to get the better results from auction, in terms of better supply chain management and better pricing, instead of various stakeholders it can be a good option to have one integrating organisation.

- The number of collections centre from all the three organisations are limited, and normally less than 100, but considering the tough and varying geographical locations in the state, these centres need to be increased, so that all farmers can have an easy access to them.

- Cultivators do not know the final destination of their crops and price in domestic and international markets. The Government can arrange a MIS (Management Information system) under Bhesag corporations from where the farmers can take the information about the price and demand of different crops. This will help farmers to cultivate the crop which will be high in demand in coming year. The government can also starts a call centre which can give information to cultivator about the market price and market demand for various crops. 
- Auction pricing can be made dynamic and can be related to the current market demands. This will yield high income for cultivators and better earnings for governments. Price control shall be done by government based on demand and supply of different crops.

- To promote the herbs and aromatic plants cultivation and sale in state, Uttrakhand government can promote the Herbal tourism in the state. It includes government certified herbal sales counters; PPP model based Herbal spas, herbal treatment, herbal massage parlours etc. This will help in further employment generation in state directly and indirectly.

\section{Limitation of Study}

- The prices referred in paper are with reference to the prices of Tanakpur Mandi, although the production data is of various districts of the state.

- Based on survey, it was found that prices remain almost stable in terms of different years for MAP products, so in this paper price reference is taken as of year 2014-15;

- $\quad$ The prices considered are from Tanakpur mandi only.

- Production is the estimated production, as some crops have fertility period of 1-3 years.

\section{Acknowledgement}

Dr V. P. Bhatt, Dr D.S. Bisht working as a Scientist at Herbal Research and Development Institute(HRDI), Gopeshwar, (Chamoli) Uttrakhand,India,Mr. Rakesh Verma, District Herb Coordinator, district Champawat, Uttrakhand, India, local cultivators of Champawat district and traders of Tanakpur mandi for sharing important informations.

\section{References}

Balwant Kumar (2009) Lichen-moss harvesting practices and their marketing strategy In Uttarakhand, India. New York Science Journal.1554-0200

Bipin Chandra Joshi and Rakesh K. Joshi (2014) The Role of Medicinal Plants in Livelihood Improvement in Uttarakhand. International Journal of Herbal Medicine 23212187

Chopra S and Meindl P (2004) Supply Chain Management. Upper Saddle River.

Deepshikha A, Joshi GC and Lalit M. Tiwari (2012) Status and trade of crude drug in Uttarakhand. Journal of Medicinal Plants Research. 1996-0875

http://archive.financialexpress.com/news/Indian-herbal-marketto-grow-by-20/292575

http://forest.uk.gov.in/pages/display/99-medicinal-aromaticplants
http://pharmabiz.com/NewsDetails.aspx?aid=71871\&sid=1

http://pib.nic.in/newsite/PrintRelease.aspx?relid=101153

http://shm.uk.gov.in/pages/display/6-state-profile

http://www.smetimes.in/smetimes/news/topstories/2010/Mar/06/indian-herbal-industry-to-double-by2015-study14569.html\#sthash.pDbrBkBl.dpuf SME Times News Bureau | 06 Mar, 2010

http://www.tribuneindia.com/2010/20100207/dplus.htm\#1

Infochange News and Features http://infochangeindia.org/agenda/agriculturalrevival/small-farmer-zindabad.html

Kumar RM and Janagam D (2011) Export and import pattern of medicinal plants in India. Indian Journal of Science and Technology. 0974- 6846

Litvinoff M and Madeley (2007). 10 reasons to buy fair trade. Available online at http://clients.squareeye.net/uploads/global/resources/10_ Reasons_to_Buy_Fair_Trade.pdf

Natural Resource India Foundation NRIF (2004) - Final Report on Pilot study on mechanism for sustainable development and promotion for herbal \& medicinal plants in the state Uttaranchal.

Nautiyal MC and Nautiyal BP (2004) Agro techniques for higher altitude medicinal and aromatic plants. High Altitude Plants Physiology Research Centre; Dehra Dun.

Phondani PC, Vikram SN, Bhatt ID, Maikhuri RK, Kothyari BP (2011) Promotion of medicated and Aromatic plants cultivation for improving lifehood security: A case study of western Himalaya, India.Int.J.Med.Arom.Plants.22494340

Polshettiwar SA (2006) Indian herbal drug industry - Future prospects: A review Ayurveda emphasis relationship between man and plants throughout the development of human culture.

Press Information Bureau Government of India (2009), Ministry of Commerce \& Industry, http://pib.nic.in/newsite/PrintRelease. aspx?relid=101153.

Rajasekharan PE, Ganeshan S (2002) Conservation of medicinal plant biodiversity in Indian perspective. Journal of Medicinal and Aromatic Plant Sciences 24(1):132-147.

Samant SS, Dhar U and Palni LMS (1998) Medicinal Plants of Indian Himalayas: Diversity, Distribution, Potential values. G.B. Pant Institute of Himalayan Environment and Development, Almora, Uttaranchal, India.

Simon Mills and Joey Lee (2011) International market prospects for sustainably sourced medicinal and aromatic plants in India. Whitley Fund for Nature - Pragya

Somashekhar I C, Raju JK, Patil H (2014) Agriculture Supply Chain Management: A Scenario in India. www.theinternationaljournal.org. 22511571

Uniyal RC, Unyal MR and Jain P (2000) Cultivation of medicinal plants in India: a reference book.Traffic India/ WWFIndia. 


\begin{tabular}{|c|c|c|c|}
\hline S.No. & Local Name & Botanical Name & $\begin{array}{c}\text { Mandi Price in } \\
\text { Rupee 2014-2015 }\end{array}$ \\
\hline 1 & Tejpat & Zanthoxylum armatum & 50 to65 \\
\hline 2 & Kilmoda & B. asiatica Roxb. & 25 \\
\hline 3 & Reetha & Sapindus mukorossi Gaertn & 15 to 25 \\
\hline 4 & Satawar & Asparagus racemosus Willd & 50 to 120 \\
\hline 5 & Peele Shatavari & Asparagus racemosus & 100 to 225 \\
\hline 6 & Kuth & Sassurea lappa C. B. Cl & 550 to 750 \\
\hline 7 & Aloe Vera & Aloe barbadensis miller & 5 to 15 \\
\hline 8 & Kapur kachri & Hedychium spicatum Buch-Ham & 100 to 175 \\
\hline 9 & Bach & Acorus Calamus & 90 to 180 \\
\hline 10 & Kadi patta & Murraya koenigii & 20 to 25 \\
\hline 11 & Badi Elaichi & Amomum subulatum & 1200 to 1400 \\
\hline 12 & Amla & Emblica officinalis Gaertn & 40 to 63 \\
\hline 13 & Baheda & Belliric Myrobalan & 40 to 70 \\
\hline 14 & Kutki & Picrorhiza kurroa Royle & 1800 to 2500 \\
\hline 15 & Artemisia & Artemisia absinthium & 50 to 150 \\
\hline 16 & Mitha & Wrightia Tinctoria & 400 to 500 \\
\hline 17 & Bichhu Ghass & Terminalia Chebula & 10 to 15 \\
\hline 18 & Lemon Grass & Cymbopogon Citratus & 450 to 700 \\
\hline 19 & Haran & Temilinalia chebula & 40 to 65 \\
\hline 20 & Samewa & V. jatamansi Jones & 40 to 50 \\
\hline 21 & Gudbach & Acorus calamus Linn & 90 to 180 \\
\hline 22 & Giloy & Tinospora Cordifolia & 30 to 50 \\
\hline 23 & Sarpagandha & Rauvolfiaserpentina Benth ex Kurz & 450 to 800 \\
\hline 24 & Thuneru & serpentina Benth ex Kurz & 200 to 250 \\
\hline 25 & Tagar & Valerianawallichi & 400 to 500 \\
\hline 26 & Chura & Aesandra butyracea (Roxb.) & 300 to 400 \\
\hline 27 & Vidari-kand & Pueraria tuberose DC & 50 to 100 \\
\hline 28 & Van Tulsi & Ocimum basilcum & 25 to 50 \\
\hline 29 & Nirguddi & Vitex Negundo Linn & 20 to 25 \\
\hline 30 & Jambu & Allium stracheyi Baker & 500 \\
\hline 31 & Stevia & Stevia rebaudiana (Bertoni) & 250 to 400 \\
\hline
\end{tabular}

* Variation in prices is because of quality of products and demand of product in market. 